\title{
FAKULTATIVNÍ ZNAKY SUBJEKTIVNÍ STRÁNKY TRESTNÉHO ČINU
}

\section{FACULTATIVE CHARACTERISTICS OF CRIMINAL OFFENCE'S SUBJECTIVE ELEMENT}

\section{Martin Mičkal ${ }^{1}$}

DOI: https://doi.org/10.24040/pros.13.11.2020.svp.177-189

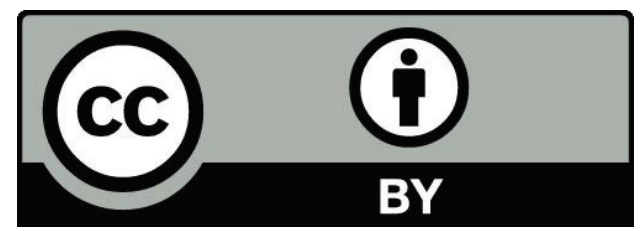

\begin{abstract}
Abstrakt
Článek se věnuje fakultativním znakům subjektivní stránky trestného činu, kterými jsou motiv (pohnutka), cíl (účel), záměr a specifický úmysl. Zejména se článek zaměř̀je na rozlišení pojmů pohnutka a specifický úmysl. Toto rozlišování má význam při posuzováni toho, zda jsou naplněny všechny zákonné znaky př́islušné skutkové podstaty v požadované kvalitě.
\end{abstract}

\section{Kl’účové slová}

subjektivní stránka, fakultativní znaky, pohnutka, motiv, úmysl přesahující objektivní stránku skutkové podstaty trestného činu, specifický úmysl, obmysl, dolus coloratus, cíl, účel

\begin{abstract}
The paper deals with the facultative characteristics of criminal offence's subjective element. These are motive (incentive), goal (purpose), intent and special intention. In particular, the article focuses on the distinction between the concepts of incentive and special intention. This distinction is important in assessing whether all the statutory characteristics of a criminal offence are met in the required quality.
\end{abstract}

\section{Keywords}

criminal offence's subjective element, facultative characteristics, incentive, motive, special intention, dolus coloratus, goal, purpose

\footnotetext{
${ }^{1}$ Mgr. Bc. Martin Mičkal, Masarykova univerzita, Právnická fakulta, Katedra trestního práva, doktorand, a Krajské státní zastupitelství v Brně, právní čekatel, e-mail: martinmickal@mail.muni.cz
} 


\section{PRÁVNE ROZPRAVY ON-SCREEN II. - Sekcia verejného práva}

online vedecká konferencia - 13. november 2020

\section{Úvod}

V právním demokratickém státě obecně platí zásada nullum crimen sine lege, tedy že není trestného činu bez zákona. Tuto zásadu je nutno chápat jako provedení zásady právní jistoty, zákazu libovůle a rovnosti před zákonem v oblasti trestního práva. ${ }^{2}$ Jde tedy o to, aby potencionální pachatel mohl v době, kdy se dopouštěl svého jednání, důvodně předpokládat, že jde o jednání trestné, a to s ohledem na obsah tehdy účinného trestního zákona, nebo tam, kde je to třeba, i s ohledem na ustálenou a obecně dostupnou judikaturu obecných soudů. Rovnost před zákonem pak znamená, že zákon by měl být vykládán pro všechny případy splňující stejné podmínky stejně ${ }^{3}$, přičemž $\mathrm{v}$ trestním řízení je rovnost před zákonem vyjádřena zásadou oficiality a legality ${ }^{4}$. Konečně nemá-li procesní postup orgánu činného $v$ trestním řízení jakýkoli normativní základ, jde o porušení zákazu libovůle ${ }^{5}$, přičemž se lze s ohledem na trestním právem chráněné právní statky důvodně domnívat, že libovůle orgánům činným v trestním řízení je zapovězena nejen v neprospěch pachatele, ale i v jeho prospěch.

\section{Trestný čin a jeho skutková podstata}

„Trestný čin jakožto skutkově - právni základ trestní odpovědnosti je vyjádřen pomocí znaků jeho prvků v zákonné skutkové podstatě coby právním základu této odpovědnosti. " ${ }^{6}$ Prvky trestného činu se rozumí objekt (předmět ochrany), objektivní stránka, subjekt a subjektivní stránka. ${ }^{7}$ „Trestněprávním vyjádřením materiální stránky trestného činu je jeho skutková podstata obsahujici typovou míru společenské škodlivosti tohoto právního deliktu vyjádřenou znaky charakterizujícími jeho prvky. “8 Pomocí těchto znaků se snaží zákonodárce přiléhavě vyjádřit typovou materiální stránku trestného činu. Konstatování viny trestným činem

\footnotetext{
${ }^{2}$ BAŇOUCH, H. Čl. 39 (Výhrada zákona při označení trestnosti jednání a druhů trestů). In: WAGNEROVÁ, E. a kol. Listina základních práv a svobod: Komentář [Systém ASPI]. Praha: Wolters Kluwer Česká republika, 2012 [cit. 2020-11-30]. Dostupné v Systému ASPI.

${ }^{3}$ Nález Ústavního soudu České republiky ze dne 20. 9. 2006, sp. zn. II. ÚS 566/05, publikováný ve Sbírce nálezů a usnesení Ústavního soudu pod č. 170/2006.

${ }^{4}$ „Zatímco zásada oficiality platí pro všechny orgány činné v trestním řizení a všechna jeho stádia, zásada legality je jejím důsledkem votázce zahájeni trestního řizeni" (KANDOVÁ, K. Trestněprocesní zásady legality a oportunity ve světle trestních teorií. Právník. 2018, č. 7. s. 587.).

${ }^{5}$ Nález Ústavního soudu České republiky ze dne 12. 5. 2020, sp. zn. IV. ÚS 1355/18.

${ }^{6}$ KRATOCHVÍL, V. Trestni právo hmotné. Obecná cást. Praha: C. H. Beck, 2012. s. 213.

${ }^{7}$ Tamtéž. s. 167

${ }^{8}$ Tamtéž. s. 194.
} 


\section{PRÁVNE ROZPRAVY ON-SCREEN II. - Sekcia verejného práva}

online vedecká konferencia - 13. november 2020

předpokládá naplnění jeho skutkové podstaty (tj. všech zákonem požadovaných znaků všech prvků trestného činu) činem konkrétního pachatele. Znaky (prvků) skutkové podstaty můžeme dělit podle toho, zda jsou, či nejsou obsažené v každé skutkové podstatě na (obecně) obligatorní a (obecně) fakultativní (oboje jsou však obligatorní v každém konkrétním případě) ${ }^{9}$

\section{Znaky subjektivní stránky trestného činu}

Obligatorním znakem subjektivní stránky je toliko zavinění ${ }^{10}$. „Zavinění je psychický vztah pachatele k poruše či ohrožení objektu trestného činu nebo jeho předmětu útoku, jakož i k jeho jednání uvedenému v trestním zákoně, které je vyvolávajï.“11 Trestní zákoník ve svém $\S 13$ odst. 2 stanovuje, že k trestní odpovědnosti za trestný čin je třeba úmyslného zavinění, nestanoví-li trestní zákon výslovně, že postačí zavinění z nedbalosti. Obě tyto formy zavinění trestní zákoník definuje $(\S 15,16)$, přičemž pro potřeby tohoto příspěvku postačí připomenout, že úmysl může být naplněn dvěma způsoby, a to jak úmyslem přímým (dolus directus), tak i úmyslem eventuálním (dolus eventualis; též jako úmysl nepřímý) ${ }^{12}$.

\footnotetext{
${ }^{9}$ Tamtéž. s. 196-198.

ŠÁMAL, P. a kol. Trestní zákoník. Komentářr. 2. vydání. Praha: C. H. Beck, 2012. s. 167.

${ }^{10}$ Zavinění se musí vztahovat na všechny objektivně-deskriptivní znaky (př́ípadně i normativní znaky) skutkové podstaty. „Okruh okolností, které musí být složkami zavinění zahrnuty, vyplývá z vymezení pojmu zavinění (\$15 a 16 trestniho zákoniku), které se vztahuje $k$ „porušení nebo ohrožení zájmu chráněného trestním zákonem“, vyvolanému spáchaným trestným činem, „způsobem uvedeným v trestním zákoně“. Vztahuje se na průběh pachatelova činu, který se projevil v objektivní realitě a odpovídá znakům skutkové podstaty trestného činu, tj. k podstatným skutečnostem, které tvoři pachatelův skutek (čin), tedy v podstatě na všechny skutečnosti, jež jsou znakem skutkové podstaty trestného činu (výjimkou jsou samožrejmě znaky subjektivní stránky - úmysl, nedbalost, pohnutka atd.), přčemž postačí, že pachatel zná reálné skutečnosti (fakta), které se těmto znaküm podřazují. Pokud by se zavinění k některé z požadovaných skutečností nevztahovalo, není dána subjektivní stránka trestného činu, a proto je vyloučena trestní odpovědnost pachatele“ (usnesení Nejvyššího soudu ze dne 24. 3. 2020, sp. zn. 8 Tdo 144/2020, bod 24).

${ }^{11}$ KRATOCHVÍL, V. Trestni právo hmotné. Obecná část. Praha: C. H. Beck, 2012. s. 279.

12 Posuzování té, či oné formy úmyslu přiléhavě formuloval Nejvyšší soud (R1/2020): „Při vědomí nutnosti určitého důsledku lze uvažovat jen o úmyslu přímém, nebot' ví-li pachatel, že určité jednání povede nezbytně $\mathrm{k}$ určitému následku, nemůže se zároveň bránit tím, že takový důsledek nechtěl. Pokud pachatel ví pouze o možnosti, že určitý následek může nastat, přicházejí v úvahu vlastně tři různé formy zavinění s ohledem na vůli pachatele - chce-li současně takový následek, jde o úmysl př́mý, nechce-li jej, ale je s ním srozuměn, jde o úmysl nepřímý, není-li s ním ani srozuměn, ale bez přiměřených důvodů spoléhá, že takový následek nenastane, jde o vědomou nedbalost. Srozuměním se rozumí (aktivní) volní vztah pachatele ke způsobení následku relevantnímu pro trestní právo. Na takové srozumění se zpravidla usuzuje z toho, že pachatel nepočítá s žádnou konkrétní skutečností, jež by mohla zabránit následku, který pachatel považuje v době jednání za možný“. Jak uvádí Kratochvíl, vůle pachatele může být orientována i na následky trestním právem aprobované, přičemž úmysl bude dán tehdy, jestliže pachatel jako podmínku dosažení beztrestného následku sledoval vyvolání následku trestněprávně významného, přičemž jako př́klad uvádí krádež peněz jako onu podmínku, s cílem zakoupit potraviny (KRATOCHVÍL, V. Trestní právo hmotné. Obecná část. Praha: C. H. Beck, 2012. s. 288).
} 


\section{PRÁVNE ROZPRAVY ON-SCREEN II. - Sekcia verejného práva}

online vedecká konferencia - 13. november 2020

V teorii i judikatuře je problematika zavinění (tj. obligatorního znaku subjektivní stránky) rozpracována velice podrobně ${ }^{13}$, je proto zajímavé, že naopak fakultativní znaky subjektivní stránky jsou teorií i (dř́ivější) judikaturou brány jako nepochybně existující, ale větší prostor jim věnován není. Tato skutečnost přispívá $\mathrm{k}$ tomu, že $\mathrm{v}$ aplikační praxi jsou činěny nesprávné14 výklady těchto zákonných znaků, což vede i k jejich nesprávné aplikaci (tj. dovozování i nesprávných konsekvencí spojovaných s jednotlivými pojmy, především požadavku na prokázání přímého úmyslu tam, kde by měl postačit úmysl eventuální). Naplnění nejen (obecně) obligatorního znaku, ale i (obecně) fakultativních znaků subjektivní stránky lze dovozovat i z objektivních skutečností, např. z povahy činu, způsobu jeho provedení nebo z jiných okolností objektivní povahy, nebot' vědomost a chtění, př́ípadně srozumění, jsou kategorie navenek seznatelné pouze tím, že o nich slovní informaci poskytne sám pachatel, nebo tím, že se projeví v jeho chování. Závěr o zavinění pachatele v době činu je závěrem právní $^{15}$, prričemž musí mít dostatečnou oporu ve skutkových zjištěních soudu vyplývajících z provedeného dokazování (R 14/2018, bod 34).

\section{Fakultativní znaky subjektivní stránky trestného činu}

Fakultativní znaky subjektivní stránky jsou cíl (účel), pohnutka (motiv), záměr ${ }^{16}$ a úmysl přesahující objektivní stránku skutkové podstaty (srov. trestním kolegiem Nejvyššího soudu záměrně upravenou právní větu u rozhodnutí publikovaného ve Sbírce soudních

\footnotetext{
${ }^{13}$ Byt' Musil připomíná, že novější české monografické práce však zcela chybějí (MUSIL, J. Několik poznámek k trestní odpovědnosti za zavinění. In: KALVODOVÁ, V., FRYŠTÁK, M., PROVAZNÍK, J. ed. Trestní právo Istále/ v pohybu: pocta Vladimíru Kratochvílovi. Brno: Masarykova univerzita, 2018. s. 270.). Připomenout lze také, že podle Musila je po zákonodárci třeba de lege ferenda požadovat, aby u předčasně dokonaných deliktů definoval subjektivní stránku trestného činu natolik určitě, aby $\mathrm{v}$ případě nepríímého úmyslu požadoval kumulativní existenci pachatelova vědění a chtění (Tamtéž. s. 279.).

${ }^{14}$ Respektive přinejmenším rozporné (navzájem diametrálně odlišné), když v aplikační praxi platí, že „správnost“ určitého výkladu musí obstát (pouze) stranami a před vyšší instancí. Lze připomenout, že dnes již bývalého státního zástupce Böhma odlišný názor soudů na tuto právní otázku dovedl až před kárný senát (rozhodnutí Nejvyššího správního soudu ze dne 13. 10. 2014, č.j. 12 Ksz 7/2014-91).

15 Je tak nepochybně možné učinit podle $\S 265 \mathrm{~b}$ odst. 1 písm. g) trestního řádu předmětem přezkumu $\mathrm{v}$ rámci dovolání (právní) závěr nižších soudů o naplnění, nebo nenaplnění zákonem požadovaných znakủ subjektivní stránky př́i zachování skutkového stavu tak, jak byl těmito soudy ustálen.

${ }^{16}$ Zřejmě rozuměn ,jednotný záměr“, který zákon vyžaduje v př́ípadě pokračování v trestné činnosti (§ 116). Kratochvíl uvádí, že záměr je jako znak subjektivní stránky pokračování v trestném činu znakem obligatorním, jeho fakultativní povaha je odvoditelná pouze z faktu, že se tato forma nevyskytuje obecně u všech trestných činů (KRATOCHVÍL, V. Trestni právo hmotné. Obecná cást. Praha: C. H. Beck, 2012. s. 275.). Byl-li by však rozuměn záměr v jiném významu, tento by měl být spíše uveden $\mathrm{v}$ závorce za cílem vedle účelu jako jejich synonyma.
} 


\section{PRÁVNE ROZPRAVY ON-SCREEN II. - Sekcia verejného práva}

online vedecká konferencia - 13. november 2020

rozhodnutí a stanovisek Nejvyššího soudu pod č. R 23/2018 ${ }^{17}$ ). Toto třídění fakultativních znaků subjektivní stránky lze považovat za správné a pro potřeby trestního práva za dostatečné. Především uvedení úmyslu přesahujícího objektivní stránku skutkové podstaty trestného činu jako samostatného fakultativního znaku je důležité. Pro tento fakultativní znak se uvádí řada synonym, byt' jak bude poukázáno dále, některé z nich mohou být sporné. Aktuální judikatura k tomuto pojmu uvádí jako synonyma (srov. slova „někdy též“") tzv. obmysl jako konečný účel, cíl jednání, tzv. dolus coloratus (R 14/2018, bod 32), tzv. druhý úmysl (R 1/2020, bod 33) či specifický úmys $1^{18}$ (usnesení Nejvyššího soudu ze dne 22. 4. 2020, sp. zn. 5 Tdo 1532/2019, bod 40).

Úmysl přesahujícího objektivní stránku skutkové podstaty trestného činu bývá někdy ztotožňován s pohnutkou. Toto je však nesprávné, nebot' i samotný trestní zákoník rozlišuje mezi těmito pojmy, a to $\mathrm{v} \S 22$ odst. 2 trestního zákoníku upravujícím nepřímé pachatelství (,...ve zvláštním úmyslu ${ }^{19}$ či z pohnutky předpokládané zákonem...“). Rozdíl mezi těmito trestněprávními pojmy popisuje Solnař následovně: „Rozdil je mimo jiné v tom, že v těchto prípadech [u úmyslu přesahujícího objektivní stránku skutkové podstaty trestného činu] stačí dolus eventualis, nikoliv však tam, kde čin musí být spáchán $k$ určitému účelu, kde je v důsledku toho třeba, aby pachatel tento následek př́mo chtěl. “" ${ }^{20}$ I Kratochvíl ${ }^{21}$ mezi těmito pojmy rozlišuje, byt' sám tomuto rozlišování nepřikládá podstatný význam, to však zřejmě proto,

\footnotetext{
${ }^{17}$ V neupravené podobě toto rozhodnutí (bod 32) znělo:,, motiv (pohnutku), nebo cíl (účel) či konečně záměr, jakožto fakultativní znak subjektivní stránky“. Úmysl přesahující objektivní stránku tak byl záměrně doplněn podle zápisu z porady trestního kolegia Nejvyššího soudu konané dne 26. 4.2018 byla tato pozměněná právní věta schválena všemi hlasy.

${ }^{18}$ Bohuslava a Pelc uvádějí, že podle italské literatury jde o opak úmyslu obecného (BOHUSLAV, L. - PELC, V. Trestný čin porušení autorského práva. In: Acta Universitatis Carolinae Iuridica. 2012, č. 4. s. 34.).

${ }^{19}$ Zvláštním úmyslem rozumí Šámal, tvưrce trestního zákoníku, specifický úmysl (srov. ŠÁMAL, P. Trestní zákoník a naplňování funkcí a základních zásad trestního práva hmotného. Bulletin advokacie. 2009, č. 10. s. 34.). Pro úplnost lze dodat, že Šámal pak rozlišuje mezi specifickým úmyslem, cílem a pohnutkou (srov. ŠÁMAL, P. K trestněprávní odpovědnosti právnických osob. Bulletin advokacie. 2011, č. 11. s. 28). Proč bylo užito slovo „Zvláštní“ namísto slova „specifický“ se autorovi nepodařilo dohledat, lze se domnívat, že „vinni“ jsou vládní legislativci, kteří mohli mít požadavek, aby nebylo užito cizí slovo „specifický“ (z lat.)., a to v souladu s čl. 40 odst. 4 Legislativních pravidel vlády, podle kterého lze cizích slov použít jen výjimečně, jsou-li součástí uživané právní terminologie, nebo užívá-li se jich běžně $\mathrm{v}$ jazyce upravovaného oboru a nelze je dost vhodně nahradit českým pojmem. $\mathrm{K}$ tomuto požadavku vládních legislativců by muselo však dojít u návrhu trestního zákoníku z roku 2004 (sněmovní tisk č. 744, 4. volební období, 2002-2006), který Poslanecká sněmovna poté, co jí byl vrácen Senátem, nepríijala.

${ }^{20}$ SOLNǍ̆, V. - FENYK, J. - CÍSAŘOVÁ, D. Systém českého trestního práva. Praha: Novatrix, 2009. Část druhá: Základy trestní odpovědnosti. S. 330. Shodně i SOLNAŘ, V. Systém československého trestního práva: Základy trestní odpovědnosti. Praha: Academia, 1972. S. 247.; SOLNAR̆, V. - FENYK, J. - CÍSAŘOVÁ, D. Systém českého trestniho práva: Základy trestni odpovédnosti. Praha: Nakladatelství Orac, s. r. o., 2003. s. 315.

${ }^{21}$ KRATOCHVÍL, V. Trestní právo hmotné. Obecná část. Praha: C. H. Beck, 2012. s. 301.
} 


\section{PRÁVNE ROZPRAVY ON-SCREEN II. - Sekcia verejného práva}

online vedecká konferencia - 13. november 2020

že pohnutku nespojuje pouze s úmyslem přímým, ale dokáže si představit i úmysl eventuální ${ }^{22}$. Slovo „úmysl“ použité v předmětném znaku je nezbytné vykládat v souladu s obecnou částí trestního zákoníku, konkrétně v souladu s $§ 15$ odst. 1 trestního zákoníku, podle kterého trestný čin je spáchán úmyslně, jestliže pachatel se jej dopustí byt' v úmyslu nepřímém.

Chce-li totiž zákonodárce vyjádřit ve skutkové podstatě požadavek na úmysl přímý, činí tak např́klad slovy „,za účelem““ (např. § 169 trestního zákoníku, § 312e trestního zákoníku) nebo „s cílem (např. § 174 trestního zákoníku, § 311 trestního zákoníku). ${ }^{23}$ Účel, stejně jako cíl, je projevem intenzity a kvality vůle, pachatel ho musí přímo chtít dosáhnout - není tedy jen srozuměn ${ }^{24}$. „Cílem (účelem) se rozumí vše trestněprávně relevantní, o co pachatel usiloval, aby svým činem vyvolal.“25 Již vzhledem k jeho smyslu je zřejmé, že zákon vyžaduje výlučně př́mý úmysl, nebot' pachatel se dopouští trestného činu „s cílem“ (za účelem), aby tohoto následku dosáhl. $\mathrm{V}$ těchto př́padech je tedy zřejmé, že by naplnění eventuálního úmyslu nepostačovalo k naplnění cíle jako podmínky trestnosti. Účelem (cílem) trestného činu je podle Solnaře to, co pachatel usiluje svým činem vyvolat. Motivem (pohnutkou) trestného činu Solnař nazývá vnitřní podnět, který vedl pachatele k rozhodnutí trestný čin spáchat, at' byl provázen city libosti či nelibosti. ${ }^{26}$ Hatala uvádí, že motiv je hnací silou k dosažení cíle, tj. stavu, v kterém se pravdou stane to, co subjekt chce, aby bylo pravdou. ${ }^{27}$ „Cíl je funkci a smyslem existence motivu, může zpětně odůvodnit i jeho obsah, není však sám o sobě odůvodněním vzniku motivu,

\footnotetext{
${ }^{22}$ Kratochvíl v časopise Státní zastupitelství napsal: „Chápeme-li specifický úmysl (tj. dolus coloratus, Absicht) vyjádřený slovy: "v úmyslu", zároven̆ jako pohnutku, motiv, které jsou v tomto typu úmyslu obsaženy, přičemž obojí (tj. pohnutka, motiv) predstavuji "... činitele zaměrující jednání pachatele $k$ určitému cíli", nebude z hlediska viny vyloučeno spojení tohoto specifického úmyslu ani súmyslem eventuálním. Pachatelem představovaný cíl jeho jednání může totiž reálně pachatel z hlediska své vi̊le pokrývat také jen pouhým srozumèním s ním, nepochybně ve formě lhostejnosti nepravé. Diskuze by mohla vyvolat však "trestněprávní lhostejnost pravá", tj. oprená o pouhé smírení se pachatele s možným následkem jeho činu. Ovšem ani tato varianta by nemusela být vyloučena, nebot' takový pachatel při představě cíle svého jednání, může být reálně s dosažením tohoto cíle jen smíren, přičemž $k$ jeho dosažení reálně ani dojít nemusí." (KRATOCHVÍL, V. Výběr judikatury. Státní zastupitelství. 2019, č. 4. s. 59.).

${ }^{23}$ Srov. ŠÁMAL, P. - PÚRY, F. - RIZMAN, S. Trestní zákon. 6. vydání, 2004. S. 35. Král záměr a cíl vysvětluje jako směřování trestného činu a pachatelem sledovaný výsledek (KRÁL, V. § 39 Stanovení druhu a výměry trestu. In: DRAŠTÍK, A. a kol. Trestní zákoník: Komentář [Systém ASPI]. Praha: Wolters Kluwer, 2015 [cit. 2020-11-30]. Dostupné v Systému ASPI. Bod 31.

${ }^{24}$ Důvodová zpráva k novele trestního zákoníku č. 455/2016 Sb. (tzv. protiteroristická novela) odkazující na Solnařùv Systém českého trestního práva. Tuto novelu (včetně její důvodové zprávy) v rámci svého tehdejšího působení na legislativním odboru Ministerstva spravedlnosti ČR zpracovával autor tohoto příspěvku, proto považuje za vhodné na to upozornit, nebot' jde o skrytou auto-citaci. Lze připomenout, že i směrnice Evropského parlamentu a Rady 2017/541 o boji proti terorismu rozlišuje pojmy za účelem (for the purpose; např. čl. 7) a v úmyslu (with the intention; např. čl. 11 odst. 1).

${ }^{25}$ KRATOCHVÍL, V. Trestní právo hmotné. Obecná část. Praha: C. H. Beck, 2012. s. 301.

${ }^{26}$ SOLNǍ̌, V. FENYK, J., CÍSAŘOVÁ, D. Systém českého trestního práva. Praha: Novatrix, 2009. Část druhá: Základy trestní odpovědnosti. s. 326.

${ }^{27}$ HATALA, V. Motiv a trestný čin. Bratislava: Vydavatel'stvo Slovenskej akadémie vied, 1968. s. 32.
} 


\section{PRÁVNE ROZPRAVY ON-SCREEN II. - Sekcia verejného práva}

online vedecká konferencia - 13. november 2020

nemůže být sám o sobě jeho dostatečnou přičinou. “28 Hatala rovněž odlišuje (na rozdíl od Solnaře) cíl od účelu trestného činu: „Cílem činu je chtěný stav. Účelem (smyslem) činu je dosáhnout tohoto chtěného stavu - cíle činu. “29 Hatala dodává, že na motiv i na účel se ptáme „proč?“, jenže u motivu odpovídáme „proto, nebot““ a u účelu zase „proto, aby“; čin je podle něj prostř̌edkem na zánik motivu a na realizování účelu. ${ }^{30}$

Důvodová zpráva k trestnímu zákoníku popisuje obmysl (tento označuje německým slovem “Absicht”) jako vůli přivodit výsledek, který je pachatelem žádán, jehož si pachatel přeje, po němž touží, a který je tedy konečným cílem (účelem jeho činnosti), kdy (před přijetím trestního zákoníku - doplnění autora) platný trestní zákon hovořil bud’ o specifickém úmyslu nebo také o účelu nebo cíli. Podstatou obmyslu je podle důvodové zprávy skutečnost, kdy pachateli záleží na tom, aby přivodil určitý výsledek, který je jím žádán nebo si ho přeje, pro nějž zákon předpokládá obmyslné jednání, a proto zpravidla spadá pod úmysl př́mý (“dolus directus”), který je u nás tradičně dobře formulován. Úmysl je totiž pojem širší než obmysl, který je pojmem užším. Zjednodušeně řečeno úmysl je vůle přivodit určitý následek, zatímco obmysl je vůle přivodit určitý následek, který je pro pachatele účelem či konečným cílem jeho činnosti.

Toto vymezení obmyslu odpovídá i starší literatuře, které jej chápala jako konečný cíl, k němuž slouží jednání jako prostředek. ${ }^{31}$ Jelínek obmyslem nazývá případy, kdy pachatelem zaviněný následek je přímým cílem, účelem jeho jednání (účel, cíl je obsahem jednání). ${ }^{32}$ Lze připomenout, že obmysl př́ímo jako zákonný znak užíval zákon č. 117/1852 ř.z., trestní zákon o zločinech, přečinech a přestupcích ${ }^{33}$ (srov. např́iklad § 46 písm. e), § 98 písm. b), § 134 či § 197), přičemž tento pojem dále upřesňoval (obmysl napřed rozvážený a vedlejší obmysl).

Obmysl („Absicht“) svým obsahem tak je daleko více synonymem pro pachatelův cíl (účel lze pak považovat za synonymum cíle). Naopak označení znaku „V úmyslu ...“34 jako

\footnotetext{
28 Tamtéž. s. 15.

29 Tamtéž. s. 33, 251.

${ }^{30}$ Tamtéž. s. 33, 251.

${ }^{31}$ Srov. např. LEPŠÍK, J. Zákon na ochranu republiky : s důvodovou zprávou. Praha: Nakladatel Fr. Borový v Praze, 1923. s. 30. Lepšík považoval za nejbezpečnější z důvodu odlišení úmyslné formy zločinu prorady podle § 4 zákona č. 50/1923 Sb., na ochranu republiky, od jednání vědomého, když se bude znakem „,V úmyslu, aby poškodil republiku“ rozumět právě obmysl.

${ }^{32}$ JELÍNEK, J. Trestní právo hmotné: obecná část, zvláštní část. 5. aktualizované a doplněné vydání. Praha: Leges, 2016. s. 225, 234. Jelínek mezi fakultativní znaky řadí pohnutku (motiv) a cíl (záměr, účel); z konstrukce dispozice vyplývá, že v případě „,cíle“ je vyžadován úmysl přímý (Tamtéž. s. 246-247).

${ }^{33}$ Respektive jeho překlad, když německá verze užívala pojem „Absicht“".

34 Je třeba poznamenat, že stejně jako slova „V úmyslu“ by se zrrejmě měly interpretovat slova ,pro výkon jeho (jejich) povinnosti“ (KRATOCHVÍL, V. Trestní právo hmotné. Obecná část. Praha: C. H. Beck, 2012. s. 301.).
} 


\section{PRÁVNE ROZPRAVY ON-SCREEN II. - Sekcia verejného práva}

online vedecká konferencia - 13. november 2020

specifického (slovy trestního zákoníku zvláštního) úmyslu, druhého (př́padně sekundárního) úmyslu či úmyslu přesahující objektivní stránku skutkové podstaty trestného činu je přiléhavé a v podstatě samo sebe vysvětlující. Problematickým může být dolus coloratus $^{35}[$ doslova barevný (barvitý, zbarvený) úmysl], který bývá uváděn historicky jako synonymum obmyslu, proto by pro něj mělo platit totéž, co bylo výše uvedeno o obmyslu. Polští autoři pod pojmem dolus coloratus rozumějí úmysl zaměřený na př́ímý účel. ${ }^{36}$

Je patrné, že o obsahu těchto pojmů a o s nimi spojených požadavcích na formu úmyslu nemá jednoznačný názor ani trestněprávní doktrína, natož právní praxe. Toto může být způsobeno i tím, že trestněprávní doktrína ne vždy reflektovala legislativní vývoj představovaný změnami v legislativní terminologii spojenými s rekodifikacemi trestního práva hmotného (především při přijetí zákona č. 86/1950 Sb., trestní zákon).

\section{Př́ístup aktuální judikatury}

Aktuálně jsou vydávány rozhodnutí k jednotlivým trestným činům obsahujícím znak „V úmyslu ...“, že postačuje pro jeho naplnění úmysl eventuální37. Tak tomu je v př́padě přečinu křivého obvinění podle $§ 345$ odst. 2 trestního zákoníku (znak „, úmyslu přivodit jeho trestní stíhání‘38), u kvalifikované skutkové podstaty téhož přečinu podle $§ 345$ odst. 3 písm. c) trestního zákoníku ${ }^{39}$, u přečinu zjednání výhody při zadání veřejné zakázky, při veřejné soutěži a veřejné dražbě podle $§ 256$ odst. 1 trestního zákoníku (R 14/20180; znak „,v úmyslu

\footnotetext{
${ }^{35}$ Rozhodnutí prvorepublikového Nejvyššího soudu sp. zn. Kr I 702/21 (Vážný 522/1921) užívalo tento pojem v následujícím kontextu: „Pro uznání zločinem velezrády je nezbytný úmysl nesporně velezrádný (ve smyslu doktríny tzv. dolus coloratus a nestačí pouhý dolus eventualis).“

${ }^{36}$ NOWAKOWSKI, J., JEDRZEJEK, C., DUTKIEWICZ, J. Assessing elements of crime based on an agent simulation of a street robbery. In: Challenge+DC@RuleML. CEUR-WS.org, 2015, č. 1417. Dostupné z: http://ceur-ws.org/Vol-1417/paper11.pdf. V anglickém originále: „,intent aiming at a direct purpose“.

${ }^{37}$ Kratochvíl situaci popsal, že jde o pokračování v nastoleném trendu, nemusí to však platit u všech trestných činů, nebot' to je otázkou budoucí judikatury (KRATOCHVÍL, V. Výběr judikatury. Státní zastupitelství. 2019, č. 4. s. 59.). Tamtéž Kratochvíl vyjadřuje názor, že „chápeme-li specifický úmysl (tj. dolus coloratus, Absicht) vyjádřený slovy: "v úmyslu", zároveň jako pohnutku, motiv, které jsou v tomto typu úmyslu obsaženy, přičemž oboji (tj. pohnutka, motiv) představujï "... činitele zaměrující jednání pachatele k určitému cíli"), nebude z hlediska viny vyloučeno spojení tohoto specifického úmyslu ani s úmyslem eventuálním. “ Je tak patrné, že Kratochvíl tak i nadále nečiní distinkce mezi probíranými pojmy, ač dospívá k témuž řešení.

${ }^{38}$ Usnesení Nejvyššího soudu ze dne 13. 5. 2020, sp. zn. 7 Tdo 479/2020.

${ }^{39}$ R 30/2019. Znak „,v úmyslu jiného vážně poškodit v zaměstnání, narušit jeho rodinné vztahy nebo způsobit mu jinou vážnou újmu,“".

${ }^{40}$ Toto rozhodnutí přiléhavě argumentovalo i tím, že ,je namistě za účelem efektivní ochrany právem chráněného zájmu na ř́dném a zákonném provedeni jakékoliv verejné soutěže nebo veřejné dražby ... trestněprávně postihovat i takové př́pady, kdy je dána i jistá míra lhostejnosti $k$ trestněprávnímu následku (dokonce postači smírení ve
} 


\section{PRÁVNE ROZPRAVY ON-SCREEN II. - Sekcia verejného práva}

online vedecká konferencia - 13. november 2020

způsobit jinému škodu nebo opatřit sobě nebo jinému prospěch"). Přečin zneužití pravomoci úřední osoby podle $\S 329$ odst. 1 TZ (R 1/2020, bod 33, rozhodnutí Nejvyššího soudu ze dne 19. 12. 2018, sp. zn. 5 Tdo 192/2018, bod 60; znak „v úmyslu způsobit jinému škodu nebo jinou závažnou újmu anebo opatřit sobě nebo jinému neoprávněný prospěch“411).

Trestněprávní nauka tytéž závěry dovozuje i u přečinu maření spravedlnosti podle § 347 a odst. 1 trestního zákoníku ${ }^{42}$ a u přečinu násilí vůči nadřízenému [ $\$ 381$ odst. 1 písm. a) i b) trestního zákoníku] $]^{43}$, judikatura $\mathrm{k}$ těmto přečinům prozatím chybí.

Jako trestné činy, kde to může být do budoucna sporné ${ }^{44}$, jsou samotnou judikaturou Nejvyššího soudu ${ }^{45}$ uváděny zločin loupeže podle $§ 173$ odst. 1 trestního zákoníku (v úmyslu zmocnit se cizí věci) a (loupežná) vraždy podle $\S 140$ odst. 3 písm. j) trestního zákoníku ${ }^{46}$. U loupeže by snad bylo možné nepř́ímo dovozovat, že je tento znak pohnutkou, z konstatování, že ,úmysl zmocnit se cizí věci může pachatel pojmout i v průběhu násilí prováděného z jiných pohnutek $^{\text {“ }}$ [R 1/1980, obdobně např. usnesení Nejvyššího soudu ze dne 6. 12. 2017, sp. zn. 8 Tdo 1470/2017, které doplňuje, že o zločin loupeže jde i tehdy, má-li být útok nebo pohrůžka útokem prostředkem (at' již výlučně nebo vedle jiných cílů) $\mathrm{k}$ tomu, aby se pachatel zmocnil cizí věci]. U (loupežné) vraždy je však zmatečný sám trestní zákoník, když znak „vv úmyslu ...“

smyslu § 15 odst. 2 tr. zákoníku). Naopak není požadováno, aby uvedený typ deliktního jednání byl postižen až v okamžiku, kdy je vedeno zvláštním záměrem, zločinnou vi̊li pachatele (v podobě chtěni) způsobit jinému škodu nebo opatřit sobě nebo jinému prospěch (pachatel jedná s úmyslem př́mým ve vztahu ke zpưsobeni škody jinému či opatřeni prospěchu sobě či jinému), nebot’ by tímto zvýšeným požadavkem na formu zaviněni nebyla poskytnuta dostatečná ochrana shora uvedenému zájmu společnosti chránènému tímto ustanovením (tzv. právnímu statku).“

${ }^{41}$ Ještě v usnesení Nejvyššího soudu ze dne 17. 2. 2010, sp. zn 7 Tdo 72/2010, byl označován tento znak jako pohnutka; Nejvyšší soud se však v tomto rozhodnutí nevyjádřil k požadované formě úmyslu.

${ }^{42}$ PROVAZNÍK, J. Trestný čin maření spravedlnosti dle § 347a trestního zákoníku. Státní zastupitelství. 2019 , roč. 16, č. 3. S. 36. Pro zajímavost lze uvést, že Provazník znak „v úmyslu, aby byl použit jako pravý,“ označuje jako specifický úmysl (dolus coloratus). Shodně též MIČKAL, M. K trestnému činu maření spravedlnosti podle $\S$ 347a trestního zákoníku. Státní zastupitelství. 2019, roč. 16, č. 6. s. 35.

43 KRATOCHVÍL, V. Trestní právo hmotné. Obecná část. Praha: C. H. Beck, 2012. s. 301.; totéž i KRATOCHVÍL, V. Judikatura. Státní zastupitelství. 2020, č. 2. S. 44, poznámka pod čarou č. 6.

${ }^{44}$ Jak bylo již výše uvedeno, i Solnař připouštěl, že i v případě úmyslu přesahující objektivní stránku trestného činu může být požadován přímý úmysl, vyplývá-li to výslovně z konkrétní formulace (tj. že je třeba, aby pachatel daný následek přímo chtěl). Jako př́iklad, kdy je třeba úmyslu přímého, Solnař uváděl formulaci „V úmyslu zajistit ... neoprávněné výhody, zajistit plnění úkolự $\mathrm{v}$ případě trestného činu porušování povinnosti při nakládání $\mathrm{S}$ finančními a hmotnými prostředky podle $§ 127$ zákona č. 140/1961 Sb., trestní zákon (SOLNǍ̌, V. - FENYK, J. - CíSAŘOVÁ, D. Systém českého trestního práva. Praha: Novatrix, 2009. Část druhá: Základy trestní odpovědnosti. s. 301.).

${ }^{45}$ Totéž podle Kratochvíla zaznělo na diskuzi trestního kolegia Nejvyššího soudu, přičemž má být v komentářích uváděno, že se vyžaduje pouze úmysl přímý (KRATOCHVÍL, V. Výběr judikatury. Státní zastupitelství. 2019, č. 4. s. 59.). Komentáře se však k dané otázce spíše nevyjadřují. Šámal k $§ 140$ odst. 3 písm. j) trestního zákoníku uvádí: „Při páchání činu ze zavrženíhodné pohnutky pachatel jedná v přimém úmyslu, avšak následek, resp. účinek smrti zde může být zpưsoben v eventuálním úmyslu podle $\$ 15$ odst. 1 písm. b), když s ním pachatel může být jen srozuměn." (ŠŚÁMAL, P. Trestní zákoník: komentář. II, § 140-421. 2. vydání. Praha: C.H. Beck, 2012. s. 1478.).

${ }^{46}$ Tato kvalifikovaná skutková podstata zní: [spáchá-li takový čin] „, úmyslu získat pro sebe nebo pro jiného majetkový prospěch nebo ve snaze zakrýt nebo usnadnit jiný trestný čin nebo z jiné zavrženíhodné pohnutky". 


\section{PRÁVNE ROZPRAVY ON-SCREEN II. - Sekcia verejného práva}

online vedecká konferencia - 13. november 2020

staví vedle pohnutky, navíc slova „nebo z jiné zavrženíhodné“ umožňují výklad, že předchozí část této alternativně formulované kvalifikované skutkové podstaty je rovněž (zavrženíhodnou) pohnutkou. Lze tak dát nejspíš za pravdu tomu názoru, že $\mathrm{v}$ daném př́ípadě jde skutečně o zištnou pohnutku, kterou však zákonodárce nedůsledně vyjádřil, přičemž tak bude platit, že získat prospěch (nebo zakrýt či usnadnit jiný trestný čin) musí pachatel přímo chtít, nestačí, aby s tím byl jen smířen ${ }^{47}$. Tuto nepřesnost trestního zákoníku lze překlenout i pravidlem, že stojíli ve skutkové podstatě vedle sebe úmysl přesahující objektivní stránku skutkové podstaty a pohnutka, je nezbytný vždy úmysl př́mý. ${ }^{48}$ Do budoucna lze doporučit, aby zákonodárce tam, kde Nejvyšší soud vyjudikuje, že znak „,v úmyslu“ lze naplnit pouze úmyslem přímým, daný znak nahradil podle povahy znakem „s cílem“ či „,za účelem“, případně přiléhavou pohnutkou, a to v zájmu snazší seznatelnosti práva.

Platí-li nullum crimen sine lege musí zákonodárce vymezit skutkové podstaty dostatečně obecně (avšak i tak dostatečně přesně), aby pokryly nejrůznorodější situace každodenního života, na druhou stranu přidáním určitého (fakultativního) znaku ${ }^{49}$ může zúžit jejich dosah na jen skutečně ty nejzávažnější případy, které považuje za trestuhodné (platí, že ne každé protiprávní jednání je trestné), prrípadně hodné trestu mírnějšího (privilegované skutkové podstaty), či přísnějšího (kvalifikované skutkové podstaty) ${ }^{50}$.

\footnotetext{
${ }^{47}$ Akceptování opačného výkladu by mohlo vést i k takovému závěru, že zavraždí-li pachatel osobu, jejímž je dědicem, vždy (bude-li co dědit) bude naplněna tato kvalifikovaná skutková podstata, ač k vraždě pachatel přistoupí z jiných, nezištných, důvodů.

${ }^{48}$ KRATOCHVÍL, V. Judikatura. Státní zastupitelství. 2020, č. 2. s. 44. Toto pravidlo však neřeší situaci u zločinu loupeže podle $\S 173$ odst. 1 trestního zákoníku.

${ }^{49}$ Kratochvíl k podsouvání dalších znaků subjektivní stránky, jako jsou cíl, pohnutka, záměr či úmysl přesahující objektivní stránku skutkové podstaty, nejsou-li přímo uvedeny v konkrétní skutkové podstatě, uvedl, že to ve svém důsledku znamená zúžení jejího dosahu. „Ovšem zúžení, jež nemá žádnou právní či jinou, napřiklad trestně politickou oporu. Zejména by tu nebylo prípustné argumentovat zásadou subsidiarity trestní represe ve smyslu $\S 12$ odst. 2 tr. zákoníku. Takovéto její pochopeni, respektive nepochopení, může nakonec vést $k$ nedůvodnému trestnímu liberalismu, respektive $k$ atrofii trestní represe, jež se jmenovanou zásadou nemaji nic společného. Máli totiž být zásada subsidiarity trestní represe skutečnou protiváhou hypertrofie trestní represe, musí vi̊č této "hypertrofii" a "atrofii" ("liberalismu") zaujímat pozici nikoliv jen pouhého jejich protipólu, nýbrž misto někde uprostřed, tedy oba zminéné protiklady ("hypertrofii" a "atrofii") vyvažovat a tím minimalizovat negativa obou krajností. Subsidiarita jako pouhý protiklad hypertrofie by mohla znamenat ztotožnění subsidiarity s atrofii trestní represe. A naopak, subsidiarita coby pouhý protiklad atrofie by mohla vést ke ztotožnění subsidiarity s hypertrofii trestni represe." (KRATOCHVÍL, V. Výběr z judikatury Nejvyššího soudu. Státni zastupitelství. 2018, č. 4. s. 49.). Není-li fakultativní znak subjektivní stránky součástí př́slušné skutkové podstaty, je možné k nim přihlédnout pouze při stanovení druhu a výměry trestu (§ 39 odst. 1, 2 trestního zákoníku), tím se jejich význam vyčerpává. Je-li však fakultativní znak subjektivní stránky př́ímo znakem skutkové podstaty, nelze k němu přihlédnout podruhé jako k okolnosti (obecně) polehčující nebo přitěžující (§ 39 odst. 5 trestního zákoníku).

${ }^{50} \mathrm{~V}$ těchto př́ípadech májí fakultativní znaky subjektivní stránky význam i ten, že stanovují jinak oproti $\S 17$ trestního zákoníku upravujícím obecně požadavky na zavinění k okolnosti zvlášt’ přitěžující.
} 


\section{PRÁVNE ROZPRAVY ON-SCREEN II. - Sekcia verejného práva}

online vedecká konferencia - 13. november 2020

\section{Závěr}

Tento příspěvek poukazuje na jisté nedostatky stávající trestněprávní nauky, jakož i na chybnou aplikační praxi a předkládá třídění fakultativních znaků subjektivní stránky trestného činu, aniž by si však činil ambice na univerzální správnost a komplexnost tohoto třídění. Rovněž př́spěvek upozorňuje na aktuální a doposud neukončený judikatorní vývoj u úmyslu přesahující objektivní stránku trestného činu jakožto jednoho z fakultativních znaků subjektivní stránky, která se podle názoru autora vydala chybně kazuistickou cestou namísto toho, aby byly vymezeny obecně platné závěry. Je tak třeba dát zákonodárci názvosloví, kterým bude moci přesně vyjadřovat vymezení skutkové podstaty, tj. typové společenské škodlivosti, aniž by hrozilo, že aplikační praxe bude dezinterpretací použitých znaků v konkrétních případech (třeba i účelově) nepřípustně zužovat její rozsah (př́ipadně i nepřípustně rozšiřovat).

\section{SEZNAM BIBLIOGRAFICKÝCH ODKAZŮ}

\section{Monografie a učebnice:}

HATALA, V.: Motív a trestný čin. Bratislava: Vydavatel'stvo Slovenskej akadémie vied, 1968. $285 \mathrm{~s}$

JELÍNEK, J.: Trestní právo hmotné: obecná část, zvláštní část. 5. aktualizované a doplněné vydání. Praha: Leges, 2016. s. 976. ISBN 978-80-7502-120-5.

KRATOCHVÍL, V.: Trestní právo hmotné. Obecná část. Praha: C. H. Beck, 2012. 921 s. ISBN 978-80-7179-082-2.

LEPŠÍK, J.: Zákon na ochranu republiky : s důvodovou zprávou. Praha: Nakladatel Fr. Borový v Praze, 1923. 176 s.

SOLNǍ̌, V - FENYK, J. - CÍSAŘOVÁ, D.: Systém českého trestního práva. Praha: Novatrix, 2009. 157, 502, 283 s. ISBN 978-80-254-4033-9.

ŠÁMAL, P. a kol.: Trestní zákoník. Komentář. 2. vydání. Praha: C. H. Beck, 2012. 3586 s. ISBN 978-80-7400-428-5.

ŠÁMAL, P. - PÚRY, F. - RIZMAN, S.: Trestní zákon. 6. vydání, 2004. 721 s. ISBN 80-7179896-7. 
PRÁVNE ROZPRAVY ON-SCREEN II. - Sekcia verejného práva

online vedecká konferencia - 13. november 2020

\section{Kapitola v učebnici nebo monografie:}

BAŇOUCH, H.: Čl. 39 (Výhrada zákona při označení trestnosti jednání a druhů trestů). In: WAGNEROVÁ, E. a kol.: Listina základních práv a svobod: Komentář [Systém ASPI]. Wolters Kluwer [cit. 2020-11-30]. Dostupné v Systému ASPI. ISBN: 978-80-7357-750-6.

KRÁL, V.: § 39 Stanovení druhu a výměry trestu. In: DRAŠTÍK, A. a kol.: Trestní zákoník: Komentář [Systém ASPI]. Praha: Wolters Kluwer, 2015 [cit. 2020-11-30]. Dostupné v Systému ASPI. ISBN 978-80-7478-790-4.

MUSIL, J.: Několik poznámek k trestní odpovědnosti za zavinění. In: KALVODOVÁ, V. FRYŠTÁK, M. - PROVAZNÍK, J. ed.: Trestní právo /stále/ v pohybu: pocta Vladimíru Kratochvílovi. Brno: Masarykova univerzita, 2018. ISBN 978-80-210-8921-1. s. 269-280.

\section{Periodiká a zborníky:}

KRATOCHVÍL, V.: Výběr z judikatury Nejvy̌šsího soudu. In: Státní zastupitelství, roč. 15, 2018, č. 4. ISSN 1214-3758. s. 45- 49.

KRATOCHVÍL, V.: Výběr judikatury. In: Státní zastupitelství, roč. 16, 2019, č. 4. ISSN 12143758. s. 54-60.

KRATOCHVÍL, V.: Judikatura. In: Státní zastupitelství, roč. 17, 2020, č. 2. ISSN 1214-3758. s. $39-46$.

KANDOVÁ, K.: Trestněprocesní zásady legality a oportunity ve světle trestních teorií. In: Právník, roč. 157, 2018, č. 7. ISSN 0231-6625. s. 582-596.

BOHUSLAV, L. - PELC, V.: Trestný čin porušení autorského práva. In: Acta Universitatis Carolinae Iuridica, 2012, č. 4. ISSN 0323-0619. s. 23-37.

ŠÁMAL, P.: Trestní zákoník a naplňování funkcí a základních zásad trestního práva hmotného. In: Bulletin advokacie, 2009, č. 10. ISSN 1210-6348. s. 22-36.

ŠÁMAL, P.: K trestněprávní odpovědnosti právnických osob. In: Bulletin advokacie, 2011, č. 11. ISSN 1210-6348. s. 19-29.

PROVAZNÍK, J.: Trestný čin maření spravedlnosti dle § 347a trestního zákoníku. In: Státní zastupitelství, roč. 16, 2019, č. 3. ISSN 1214-3758. s. 27-36.

\section{Internetové zdroje:}

NOWAKOWSKI, J. - JEDRZEJEK, C. - DUTKIEWICZ, J.: Assessing elements of crime based on an agent simulation of a street robbery. In: Challenge+DC@RuleML. [online] CEUR- 
PRÁVNE ROZPRAVY ON-SCREEN II. - Sekcia verejného práva

online vedecká konferencia - 13. november 2020

WS.org, 2015, č. 1417. [cit. 2020-11-30]. Dostupné na internetu: http://ceur-ws.org/Vol1417/paper11.pdf 